\title{
Strategies to maximise establishment and production of oversown caucasian clover
}

\author{
W.L. LOWTHER ${ }^{1}$, HEATHER N. PRYOR ${ }^{1}$ and K.D. TRAINOR ${ }^{2}$ \\ ${ }^{1}$ AgResearch, Invermay Agricultural Centre, PB 50034, Mosgiel \\ ${ }^{2}$ AgResearch, PO Box 228, Alexandra
}

\begin{abstract}
Caucasian clover (Trifolium ambiguum M. Bieb.) is an alternative legume for areas where white clover (T. repens L.) growth is limited. However, slow establishment has been a problem when caucasian clover has been oversown. Results from two tussock grassland sites have demonstrated the importance of the initial establishment of caucasian clover. Caucasian clover dry matter production after 6 years was still related to original seedling establishment. This result was obtained in ungrazed swards, conditions likely to maximise the ability of caucasian clover to spread by rhizomes and natural reseeding. The results indicate that caucasian clover may make little contribution to legume yield in these environments for at least 6 years unless satisfactory numbers of plants are established initially. Maintenance fertiliser application, in early years at least, appears similar to that required by white clover. Yields of caucasian clover swards in the $6^{\text {th }}$ year when maintenance fertiliser had been applied were 3-7 times those when fertiliser had been applied only at sowing. The paper also provides possible explanations for establishment failures that have already occurred, and provides information on correct management techniques to maximise establishment of oversown caucasian clover.
\end{abstract}

Keywords: caucasian clover, establishment, fertiliser, hill country, inoculation, nodulation, oversowing, pasture, Trifolium ambiguum the Bay of Plenty (Watson et al. 1996). However, in contrast to the consensus on the agronomic attributes, slow establishment has been identified by some researchers as a problem where caucasian clover has been oversown and a possible restriction to its use (Lucas et al. 1981; Moorhead et al. 1994).

Previous experience in hill and high country environments has illustrated the necessity of overcoming establishment limitations before recommending the use of new legumes in farming practice. Results presented in this paper demonstrate the importance of maximising the establishment of caucasian clover, provide possible explanations for establishment failures that have already occurred, and provide establishment recommendations for oversowing caucasian clover.

\section{Effect of establishment and maintenance fertiliser on productivity of caucasian clover}

\section{Materials and methods}

Two sites (Table 1) from the establishment trials reported on by Patrick \& Lowther (1995) were used to determine the effect of the initial establishment on longer-term productivity of caucasian clover. The medium-altitude (760 m a.s.1.) site on the Pisa Range was a modified fescue tussock (Festuca novae-zelandiae) grassland with up to $50 \%$ bare ground in some plots. The soil was a yellow-grey earth with $\mathrm{pH}$ 5.7; soil $\mathrm{P}$ and $\mathrm{S}$ levels are given in Table 2. The higher-altitude $(1120 \mathrm{~m})$ site on the Crown Range was a modified snow tussock grassland site with up to $30 \%$ bare ground. The soil was a yellowbrown earth with $\mathrm{pH}$ 5.1.

\section{Introduction}

From previous papers at New Zealand Grassland Association conferences, there is a clear consensus that caucasian clover (Trifolium ambiguum M. Bieb) is a persistent and productive alternative pasture legume where environmental factors (e.g., moisture) or insects limit white clover (T. repens L.) growth. Environments reported on include the tussock grasslands (Allan \& Keoghan 1994), dry hill country (Daly \& Mason 1987), dry Canterbury plains (Moss et al. 1996) and dairy pastures in
Table 1 Effect of inoculation level on nodulation after 4 months and seedling establishment after 7 months on two sites.

\begin{tabular}{lccccc}
\hline $\begin{array}{l}\text { Site: } \\
\text { Inoculation } \\
\text { level }\end{array}$ & $\begin{array}{c}\text { Rhizobia } \\
\text { per seed } \\
\left(\times 10^{3}\right)\end{array}$ & $\begin{array}{c}\text { Seedling } \\
\text { nodulation } \\
(\%)\end{array}$ & $\begin{array}{c}\text { Seedling } \\
\text { establish. } \\
\left(\text { No. } / \mathrm{m}^{2}\right)\end{array}$ & $\begin{array}{c}- \text { Seedling } \\
\text { nodulation } \\
(\%)\end{array}$ & $\begin{array}{c}\text { Seedling } \\
\text { establish. } \\
\left(\text { No. } / \mathrm{m}^{2}\right)\end{array}$ \\
\hline $0.008 \times \mathrm{N}$ & 0.2 & 3 & 2 & 3 & 1 \\
$0.04 \times \mathrm{N}$ & 0.9 & 14 & 2 & 6 & 2 \\
$0.2 \times \mathrm{N}$ & 2.3 & 18 & 3.5 & 13 & 2 \\
$\mathrm{~N}^{1}$ & 23 & 58 & 9 & 39 & 12 \\
$6.3 \times \mathrm{N}$ & 260 & 79 & 33 & 48 & 17 \\
SED & & 7.7 & 4.1 & 7.7 & 4.1 \\
\hline
\end{tabular}

$1 \mathrm{~N}=$ manufactures stipulated rate of $9.6 \mathrm{~g}$ peat inoculant per $\mathrm{kg}$ seed Derived from Patrick \& Lowther (1995) 
Table 2 Changes in soil $P$ and $S$ levels ${ }^{1}$ with $200 \mathrm{~kg} / \mathrm{ha}$ Mo-Ssuperphosphate at sowing and either no maintenance fertiliser or $150 \mathrm{~kg} / \mathrm{ha}$ of S-superphosphate applied in year 3 .

\begin{tabular}{llrcr}
\hline Site & Nutrient & Year 1 & $\begin{array}{c}\text { No } \\
\text { maintenance }\end{array}$ & $\begin{array}{c}\text { Maintenance } \\
\text { fertiliser }\end{array}$ \\
\hline Pisa & Olsen-P $(\mu \mathrm{g} / \mathrm{g})$ & 18 & 27 & 28 \\
Pisa & Extract. S $(\mu \mathrm{g} / \mathrm{g})$ & 6 & 2 & 9 \\
Crown & Olsen-P $(\mu \mathrm{g} / \mathrm{g})$ & 14 & 15 & 21 \\
Crown & Extract. S $(\mu \mathrm{g} / \mathrm{g})$ & 3 & 5 & 16
\end{tabular}

1 MAF Quick test (Cornforth \& Sinclair 1984)

A basal dressing of $200 \mathrm{~kg} / \mathrm{ha}$ S-Mo-superphosphate $(19 \% \mathrm{~S} ; 0.01 \% \mathrm{Mo} ; 8 \% \mathrm{P})$ was applied to all plots. The equivalent of $5 \mathrm{~kg} / \mathrm{ha}$ bare seed $(\mathrm{germ} .=78 \%$ ) of caucasian clover, inoculated at rates from 0.008 to 6.3 times the manufacturer's stipulated rate, was sown in spring 1992. The number of established plants was counted 7 months later. During winter 1996, $150 \mathrm{~kg} / \mathrm{ha}$ S-superphosphate was applied to two, of the four, replicates on each site. The effects of the initial establishment and of maintenance fertiliser on caucasian clover dry matter (DM) production were determined in January 1998. A regression analysis was used to determine the relationship between initial establishment and caucasian clover DM in year 6 .

\section{Results and discussion}

Increasing the number of rhizobia applied to the seed from 0.2 to $260 \times 10^{3}$ increased the number of plants established, 7 months after sowing, from 2 to 33 and 1 to $17 / \mathrm{m}^{2}$ at Pisa and Crown Range, respectively (Table 1).

Figure 1 Effect of seedling establishment on caucasian clover DM in year 6 with either no maintenance fertiliser or $150 \mathrm{~kg} / \mathrm{ha}$ of S-superphosphate applied in year 3 .

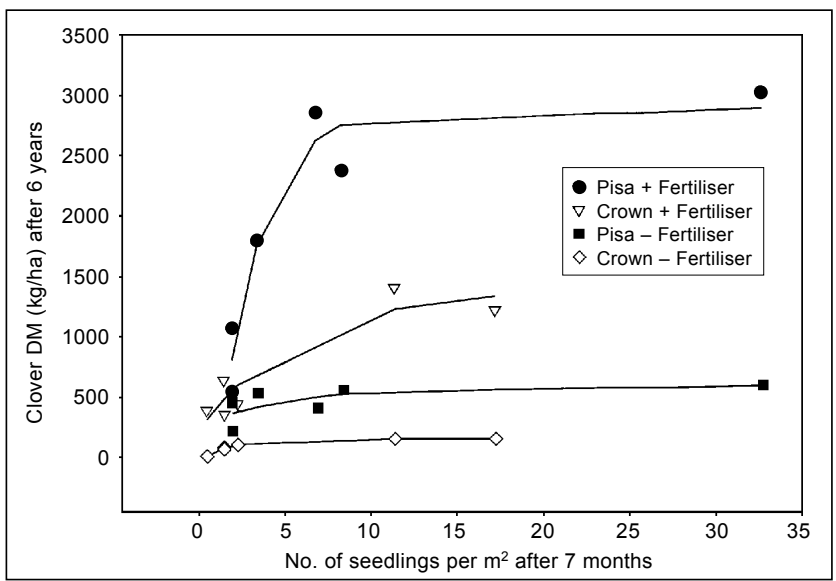

In year 6, little caucasian clover growth was recorded in the plots that had not received the maintenance fertiliser dressing, irrespective of initial establishment (Figure 1). The present results reinforce the conclusions of Lucas et al. (1981) that there is little evidence that caucasian clover is a fertiliser-efficient plant. The lack of growth in the absence of maintenance $\mathrm{S}$-superphosphate in the present experiment can be attributed mainly to S, as Olsen-P levels (Table 2) are in the range considered to be satisfactory (Cornforth \& Sinclair 1984). The long-term persistence of caucasian clover in the absence of maintenance fertiliser has been attributed to the ability of caucasian clover to retain nutrients in the root biomass (Strachan et al. 1994). The present results suggest that this will depend on either high initial rates of fertiliser, or several years of annual maintenance fertiliser application, to allow the plant to build up these root reserves.

Maintenance S-superphosphate application markedly increased caucasian clover DM but the response was affected by the initial establishment. On both sites, caucasian clover DM increased as the number of seedlings increased (Figure 1), with $88 \%$ and $72 \%$ of the variation in caucasian clover DM at the Pisa and Crown Range sites, respectively, being accounted for by the initial establishment $(\mathrm{P}<0.05)$.

Caucasian clover can spread by rhizome expansion (Allan \& Keoghan 1994) and by natural reseeding (Pryor et al. 1996). However, at low levels of seedling establishment in the present experiment $(<5$ seedlings/ $\mathrm{m}^{2}$ ), potential production of caucasian clover swards was still limited 6 years after sowing, even in the absence of grazing where both rhizome expansion and reseeding should have been optimised. Lucas et al.

(1981) reported that productivity of caucasian clover swards increased over 5 years after sparse establishment of 4.5 plants $/ \mathrm{m}^{2}$. The present results, and those of Lucas et al. (1981), were obtained with seeding rates of 5 and $4 \mathrm{~kg} / \mathrm{ha}$, respectively, and it is likely that the seeding rates used in farming practice will be lower.

The present results support the conclusion of Lucas et al. (1981) that poor establishment of caucasian clover after oversowing will be a major limitation to productivity for several years and may restrict its use. A particular concern is that the low productivity of swards resulting from poor establishment may convince farmers that it is not economically justifiable to use caucasian clover. It is therefore important that farmers are aware of the correct establishment technology. 


\section{Strategies to maximise caucasian clover establishment}

\section{Early seedling establishment}

Previous research on establishment of white clover provides relevant information on management practices to improve early seedling establishment of caucasian clover. This is important, as the larger seed size in hexaploid caucasian clover $(2.25 \mathrm{~g} / 1000$ seeds $)$ than white clover $(0.71 \mathrm{~g} / 1000$ seeds $)$ will result in approximately $1 / 3$ the number of caucasian clover seeds applied when the two legumes are sown at the same seeding rate per ha.

When $4 \mathrm{~kg} / \mathrm{ha}$ seed was oversown at Mesopotamia, a dense population of white clover established but caucasian clover establishment was sparse, with only 4.5 plants $/ \mathrm{m}^{2}$ (Lucas et al. 1981). In contrast, Lowther \& Patrick (1992) found that germination and early seedling establishment, as a percentage of white clover and caucasian clover seed oversown, was similar over a range of tussock grassland sites. The low establishment reported by Lucas et al. (1981) was probably due to nodulation failure, as there were many small yellowgreen seedlings. In both these experiments, seed was oversown into low-producing natural grasslands in early spring where frost had opened up the vegetation and produced favourable microclimates on the soil surface for germination. Glasshouse trials have suggested that early seedling establishment of caucasian clover may be lower than white clover in more marginal conditions owing to slower germination (Awan et al. 1996) and difficulty of the radicle entering the soil (Todhunter 1997). The presence of Hieracium is likely to provide less favourable environmental conditions for germination, as it has been shown to prevent seed reaching the soil surface (Moorhead et al. 1994).

In much of the undeveloped, low-fertility tussock grassland in the sub-humid to humid zone, control of existing vegetation has not been necessary for the establishment and survival of oversown white clover. However, the spread of Hieracium in the tussock grasslands is likely to reduce caucasian clover seedling survival (Lucas et al. 1981). Competition from Hieracium will be more intense where soil moisture is limiting (i.e., low rainfall sunny faces), such as the 860 m Queensberry site where Patrick \& Lowther (1995) reported that most plants disappeared over summer owing to drought stress. In semi-arid environments, herbicide application may be necessary to control existing vegetation and reduce competition for moisture over the first summer (Rhodes \& Clare 1983).

In North Island hill country pasture, stock trampling to improve seed/soil contact and pre- and post-sowing stock grazing to reduce competition is critical for successful establishment following oversowing (Macfarlane \& Bonish 1986). Similar management techniques would overcome many of the problems that have been identified with establishment of oversown caucasian clover in South Island hill and high country.

Oversowing in late winter or early spring when there is the greatest chance of soil and weather conditions being suitable for establishment is recommended for the tussock grasslands (Musgrave 1977). However, even when sown at this time, environmental conditions can still play an overriding influence. For example, on adjacent sites in the Maniototo, Pryor et al. (1998) reported that with identical inoculation rates, seed sown 2 weeks apart resulted in $24 \%$ and $80 \%$ of seedlings nodulated. The low seedling nodulation at the first sowing was attributed to a rapid death of rhizobia on the seed owing to dry conditions. At the second sowing, the soil was wet and $25-30 \mathrm{~mm}$ of rainfall was recorded on the day of sowing. During the severe spring-summer drought in 1997/98 in the Maniototo, establishment of oversown caucasian clover failed on our sites where good establishment had been recorded previously. Autumn oversowing, as used in North Island hill country (Macfarlane \& Bonish 1986), should reduce the risk of establishment failure from summer drought. However, frost kill of seedlings can occur after autumn oversowing in South Island tussock grasslands.

\section{Nodulation}

Caucasian clover has very specific nodulation requirements and therefore inoculation of seed with the correct strain of rhizobia is essential (Patrick \& Lowther 1995). However, when seed is oversown there can be rapid death of rhizobia, and Patrick \& Lowther (1995) showed that high rates of inoculation and pelleting with gum arabic and lime are necessary for satisfactory levels of nodulation and establishment (Table 1).

Although suitable for experimental sowings of small quantities of seed, this recommendation is not suitable for large-scale sowings. Low seedling nodulation, and hence establishment, is likely where commercially pelleted seed is oversown unless high numbers of rhizobia are present (Patrick \& Lowther 1995). For example, Moorhead et al. (1994) reported that $80 \%$ of seedlings were small and yellow with either no nodules or small pale nodules 5 months after oversowing with commercially pelleted seed. In contrast, this commercially pelleted seed was effective when drilled, indicating that the number of rhizobia required on the seed at sowing is lower when seed is placed in the soil.

Because of the widespread use of commercially pelleted seed in New Zealand for both oversowing and drilling, development of effective commercial products is a priority. Improvements in establishment and growth 
have been obtained from the selection of a strain of rhizobia more adapted to inoculant use (Pryor et al. 1998) but, even with the new strain of rhizobia, high numbers of rhizobia on the seed will still be required for oversowing.

\section{Conclusions}

The results show the importance of maximising the establishment of caucasian clover oversown into tussock grasslands. With low seedling establishment, productivity of caucasian clover will be limited for several years until swards thicken up by rhizome expansion. Although caucasian clover can persist at low levels of fertiliser, productive swards appear to require maintenance fertiliser rates similar to white clover, at least in early years. Because of the absence of caucasian clover rhizobia from New Zealand soils, effective inoculation is essential. Under oversowing conditions, successful nodulation requires high numbers of rhizobia on the seed at sowing. Germination, survival and growth of seedlings depends on selection of suitable areas, correct time of sowing and appropriate pre- and postsowing management.

\section{ACKNOWLEDGEMENTS}

Wrightson Seed Ltd for supply of seed. Esmond Cooke, Waitiri Station and Liz Fastier, Queensberry Hills for providing on-farm trial sites. This work was funded by the New Zealand Foundation for Research, Science \& Technology.

\section{REFERENCES}

Allan, B.E.; Keoghan, J.M. 1994. More persistent legumes and grasses for oversown tussock country. Proceedings of the New Zealand Grassland Association 56: 143-147.

Awan, M.H.; Barker, D.J.; Kemp, P.D.; Choudhary, M.A. 1996. Soil surface moisture measurement and its influence on the establishment of three oversown legume species. Journal of agricultural science, Cambridge 127: 169-174.

Cornforth, I.S.; Sinclair, A.G. 1984. Fertiliser and lime recommendations for pastures and crops in New Zealand. Wellington, New Zealand Ministry of Agriculture and Fisheries.

Daly, G.T.; Mason, C.R. 1987. Performance of caucasian and zigzag clovers. Proceedings of the New Zealand Grassland Association 48: 151-161.

Lowther, W.L.; Patrick, H.N. 1992. Seedling establishment characteristics of alternative legume species in tussock grassland environments. Proceedings of the New Zealand Grassland Association 54: 111114.
Lucas, R.J.; White, J.G.H.; Daly, G.T.; Jarvis, P.; Meijer, G. 1981. Lotus, white clover and Caucasian clover oversowing, Mesopotamia Station, South Canterbury. Proceedings of the New Zealand Grassland Association 42: 142-151.

Macfarlane, M.F.; Bonish, P.M. 1986. Oversowing white clover into cleared and unimproved North Island hill country - The role of management, fertiliser, inoculation, pelleting and resident rhizobia. Proceedings of the New Zealand Grassland Association 47: 43-51.

Moorhead, A.J.E.; White, J.G.H.; Jarvis, P.; Lucas, R.J.; Sedcole, J.R. 1994. Effect of sowing method and fertiliser application on establishment and first season growth of Caucasian clover. Proceedings of the New Zealand Grassland Association 56: 91-95.

Moss, R.A.; Burton, R.N.; Allan, B.E. 1996. Productivity of caucasian clover based pastures under irrigation. Proceedings of the New Zealand Grassland Association 58: 177-181.

Musgrave, D.J. 1977. Effects of time of sowing on the establishment of oversown legumes. Proceedings of the New Zealand Grassland Association 38: 160166.

Patrick, H.N.; Lowther, W.L. 1995. Influence of the number of rhizobia on the nodulation and establishment of Trifolium ambiguum. Soil biology \& biochemistry 27: 717-720.

Pryor, H.N.; Lowther, W.L.; McIntrye, H.J.; Ronson, C.W. 1998. An inoculant Rhizobium strain for improved establishment and growth of hexaploid Caucasian clover (Trifolium ambiguum). New Zealand journal of agricultural research 41: 179189.

Pryor, H.N.; Lowther, W.L.; Trainor, K.D. 1996. Natural reseeding of caucasian clover (Trifolium ambiguum) in tussock grasslands. Proceedings of the New Zealand Grassland Association 58: 171-175.

Rhodes, P.J.; Clare, R.J. 1983. Legume oversowing on hill country in Marlborough. Proceedings of the New Zealand Grassland Association 44: 142-148.

Strachan, D.E.; Nordmeyer, A.H.; White, J.G.H. 1994. Nutrient storage in roots and rhizomes of hexaploid Caucasian clover. Proceedings of the New Zealand Grassland Association 56: 97-99.

Todhunter, C.J. 1997. Establishment of Caucasian clover compared with white clover and red clover. Dissertation for the Degree of BAgSci(Hons). Lincoln University.

Watson, R.N.; Neville, F.J.; Bell, N.L.; Harris, S.L. 1996. Caucasian clover as a pasture legume for dryland dairying in the coastal Bay of Plenty. Proceedings of the New Zealand Grassland Association 58: 183-188. 